\title{
Kirjoja koulutuksen ja työelämän yhteistyöstä sekä työssä oppimisesta
}

\author{
Osmo Kivinen, Heikki \\ Silvennoinen \& Pia \\ Puustelli (toim.) 1999. \\ Work-based learning. \\ Prospects and chal- \\ lenges. Helsinki: \\ Ministry of Education. \\ Pekka Ruohotie, Juha- \\ ni Honka ja Antti Su- \\ vanto (toim). 1999.The \\ Developmental Chal- \\ lenges in the Coopera- \\ tion of Education and \\ Training and Working \\ Life. Helsinki: EDITA.
}

Koulutuksen ja työelämän välinen yhteistyö ja työssä oppiminen ovat uusia ja voimakkaasti kasvavia tutkimusalueita sekä kansainvälisesti että kotimaassa. Niinpä näihin teemoihin keskittyvien kahden kotimaisen kirjan ilmestyminen on tervetullut tapahtuma.

Kivisen, Silvennoisen ja Puustellin toimittama kirja tarjoaa sosiologisen lähestymistavan työssä oppimiseen. Se etsii myös historiasta syitä sille, miksi koulutuksen ja työelämän välisiä raja-aitoja ollaan juuri nyt purkamassa ja miksi työssä oppiminen kaikkine ilmenemismuotoineen puhuttaa jälleen. Kirjassa siis pyritään ottamaan huomioon laajasti ne kentät ja olosuhteet, joissa työssä oppimista tapahtuu. Ammatillisen koulutuksen toteuttamisen kuvauksessa on pyritty kriittisesti ottamaan huomioon sekä yh- teiskunnallisia että yksilöllisiä näkökulmia. Teoksen vahvuus piilee sen laaja-alaisessa otteessa.

\section{Kirjan ensimmäisessä} kappaleessa kirjoittajat pohtivat nykykritiikkiä, joka on kohdistettu institutionalisoitua ammatillista koulutusta kohtaan. Kirjoittajat korostavat julkisen koulutussysteemin vastuullista roolia uusien ammattitaitovaatimusten toteuttajana ja tuovat vahvasti esille koulutuksen ja työelämän yhteistyön tärkeyden.

\section{Toisessa kappaleessa}

Heikki Silvennoinen tarkastelee sitä, miten formaaleissa ja nonformaaleissa yhteyksissä, lähinnä työssä, opitaan. Siinä pohditaan myös sitä, mitä opitaan koulussa ja mitä siellä on mahdollista oppia. Kirjoittaja kuvaa laajasti työelämässä vaadittavaa osaamista. Sen sijaan oppimisesta, työprosesseista, työntekijän kokemuksesta tai työstä itsestään hän ei puhu paljonkaan. Oppiminen työntekijän kokemuksena ja se, mitä tämän kokemuksen tunnistaminen voisi merkitä ammattiin oppimisessa, jää avoimeksi. Jos siis väitetään, että pelkästään koulun antama tieto-taito ei enää riitä työelämässä, tulisi em. seikat huomioon ottaenkin vakavasti ryhtyä pohtimaan, miten erilaisia oppimisympäristöjä voitaisiin integroida. Em. haasteen pohtiminen ei ollut tässä kirjassa tarkastelun ensisijaisena tavoitteena, vaikka kirjan toinen kappale herättää lukijassa tämän suuntaisia kysymyksiä.

\section{Seuraavassa neljässä} kappaleessa - kirjoittajina Sakari Ahola ja Heikki Silvennoinen, Osmo Kivinen ja Mikko Peltomäki sekä Petri Haltia - kuvataan erilaisia työssä oppimisen toteuttamistapoja Suomessa ja muualla Euroopassa. Koulutuksesta työhön siirtymistä on ryhdytty useissa maissa tukemaan erilaisin ohjelmin pyrkimällä samalla ehkäisemään nuorisotyöttömyyttä ja syrjäytymistä. Vanha fakta tuntuu edelleen pitävän paikkaansa: koulutus valmistaa ensisijaisesti työmarkkinoille, ei suoraan työpaikkoihin.

\section{Työharjoittelun}

toteuttamismalleja etsitään kirjassa mm. Saksasta, Tanskasta ja Iso-Britanniasta. Näiden pohjalta luodaan suomalaiseen kulttuuriin ja yhteiskuntaan sopiva ammatillisen koulutuksen työssä oppimisen malli, jossa työelämän olosuhteet ja yksilön (opiskelijan) tarpeet voisivat kohdata tavalla, joka muistuttaisi aitoa yrittäjyyttä. Oppisopimuskoulutus on Suomessa sen sijaan ollut aina harvinaisempi tapa oppia työssä, mikä johtuu mm. työnantajien joiltain osin kriittisestä asenteesta sekä osittain myös siksi, että ammatillisen koulutuksen toteuttamisella on Suomessa aina ollut kytkentänsä ammattijärjestöihin ja sosiaalipoliittisiin ongelmiin, esimerkiksi työttömyyteen ja sen hoi- 
toon. Tarkasteltaessa oppisopimuskoulutuksen tulevaisuutta nousee jälleen keskeiseksi kysymykseksi, mitä voidaan oppia koulussa ja mitä työssä.

\section{Vuodesta 1994 lähtien}

Suomessa on ollut myös mahdollista akkreditoida formaalin koulutuksen ulkopuolella opittuja taitoja näyttötutkinnoilla. Näyttötutkintosysteemin tavoitteena on lähentää suomalaista ammatillista koulutusta ja työelämää rationalisoimalla koulutusta ja motivoimalla ihmisiä kehittämään itseään ja ammattitaitoaan. Tutkimusten mukaan näyttötutkinnoilla ei kuitenkaan välttämättä saada esiin niitä taitoja, joita työelämässä todella tarvitaan.

\section{Heikki Silvennoisen}

kirjoittama seuraava kappale sisältää eri tasoisia asiakokonaisuuksia, mikä tekee siitä myös hieman vaikeaselkoisen. Kappaleessa tarkastellaan kansalaisia, työnantajia ja valtiota koulutustarpeiden määrittäjinä ja tämän määrittämisen vaikutuksia työssä oppimiselle. Vaikka koulun ja työelämän yhteistyöstä on myös rohkaisevia esimerkkejä, todennetaan tutkimustiedoin edelleen olemassa olevaa ongelmaa: sekä työnantajat että opettajat toteavat, ettei heillä ole tietoa, kiinnostusta, vastuuta eikä halua pitää huolta koulun ja työelämän välisestä yhteistyöstä. Mihin siis silloin työssä oppiminen voi perustua? Jo työelämässä toimivien osaamiskapasiteettia ei tutkimusten mukaan käytetä täysipainoisesti, kun suuri osa työtehtävistä on työntekijöiden mukaan opittavissa muutamassa viikossa tai muuta- massa kuukaudessa, enintään parissa vuodessa. Herää myös kysymys, millaisia muotoja henkilöstönkehittäminen ja työssä oppiminen silloin saa tai sen pitäisi saada?

\section{Viimeisessä kappaleessa}

Osmo Kivinen ja Heikki Silvennoinen kokoavat sujuvasti kirjan avaamia näkökulmia teoreettisten jäsennysten avulla. Kirjoittajat toteavat pessimistisesti työssä oppimista tukevien uudistusten olevan perimmältään riippuvaisia yritysten asemasta markkinoilla ja työvoiman jakautumisesta. Työssä oppimisen muodot tekevät kuitenkin uutta tuloaan teoretisointien ja tutkimustenkin valossa ja pitkällä tähtäimellä yrityksetkin hyötyvät työssä oppimisen toteuttamisesta. Hyöty tulee myös kirjoittajien määritelmän kautta: ammattitaito on luonteeltaan sosiaalista ja kuvastaa sitä kontekstia, jossa taitoa käytetään.

\section{Kirja "The Developmental} Challenges in the Cooperation of Education and Training and Working Life" koostuu kaikkiaan 13 artikkelista, jotka käsittelevät työtä ja koulutusta pääasiassa oppimisen näkökulmasta. Teos on jaettu kahteen osaan, joista ensimmäisessä käsitellään lähinnä ammatillista kasvua työelämässä ja toisessa pedagogisen kehittämistoiminnan haasteita. Johdannossa esitellään Tampereen yliopistossa toimivan ammatillisen koulutuksen tutkimuskeskuksen toimintaa ja meneillään olevia tutkimusprojekteja, niissä toimivia tutkijoita sekä Suomen- ja Euroopan laajuisia yhteistyöverkostoja. Artikkelit perustuvat pääosin laitoksessa tehtyyn tutkimustyöhön.

Kirjan aloittaa Juhani Hongan ja Pekka Ruohotien

"Kannustava ja palkitseva johtaminen" -kirjaan perustuva artikkeli, jonka tarkoituksena on välittää popularisoitua tietoa työkäyttäytymisen tutkimuksesta. Aihetta tarkastellaan motivationaalisena ilmiönä, ja artikkelissa esitellään tekijöitä, jotka vaikuttavat työkäyttäytymiseen ja tekevät työstä yksilölle tyydytystä antavaa, mutta samalla työnantajalle kannattavaa. Avainsanoja ovat motivaatio, sitoutuminen, palaute, palkitseminen. Teemaa tarkastellaan johdon näkökulmasta eli miten hyvä johtaja pystyy ottamaan nämä tekijät huomioon ja luomaan sekä työntekijän että työnantajan kannalta hyvät työolosuhteet. Ikään kuin käytännöllisenä ohjeistona artikkeli poikkeaa tyyliltään kirjan muista artikkeleista, jotka edustavat enemmän tieteellisen kirjoittamisen konventioita.

\section{Toisessa artikkelissa}

Pekka Ruohotie tarkastelee vuorovaikutukseen perustuvan oppimisen kysymyksiä yksilöllisen urakehityksen kannalta. Eräänlaisena ideaalina esitellään muuntaumiskykyinen ura, jolle on ominaista horisontaalinen kasvu eli kompetenssin ja verkostojen laajentuminen uran edetessä. Pekka Ruohotien ja Matti Koirasen kirjoittama seuraava artikkeli tutkiskelee persoonallisuuden kehityksen ja motivaation peruskäsitteitä ja soveltaa niitä yrittäjyyskasvatukseen. Näissä molemmissa artikkeleissa on vahva teoreettinen ote ja ne tarjoavat hyvän ja kiinnostavan johdannon näiden tutkimusalueiden peruskäsitteisiin ja teoriaan. 


\section{Pauli Juuti pohdiskelee}

filosofis-sosiologisessa kirjoituksessaan kompetenssia postmodernin organisaation ja oppivan organisaation näkökulmasta. Juuti näkee oppivassa organisaatiossa kolme erilaista dilemmaa. Ensinäkin organisaatio tavoittelee organisoitua toimintaa, kun taas oppiminen toimintana tavoittelee muutosta. Toinen dilemma koskee jännitettä yksilön ja yhteisön oppimisen välillä. Kumpikaan oppimisen muoto ei yksinään ole pystynyt selittämään sitä, millaista oppimista organisaatiossa tapahtuu. Oppivan organisaation kolmas dilemma on kognitioiden korostaminen jokapäiväisen sosiaalisen vuorovaikutuksen ja diskurssien jäädessä marginaaliin. Ratkaisua näihin dilemmoihin etsittäessä on Juutin mukaan käännyttävä poststrukturalismin ja sosiaalisen konstruktionismin suuntaan.

\section{Seuraavissa luvuissa}

- kirjoittajina Kaisa KauttoKoivula, Outi Raehalme ja Marja-Liisa Manka - kuvataan tutkimuksia työpaikoista oppimisympäristöinä. Artikkeleiden kautta välittyy ajatus, että työssä oppiminen, joko formaalin koulutuksen tai informaalin oppimisen kautta, on suorastaan välttämättömyys sekä yksilön että koko organisaation kannalta. Näiden kolmen vahvasti empiirisen tutkimuskuvauksen jälkeen lukija yllättyy artikkelista, jossa palataan jälleen teoreettis-filosofiseen pohdiskeluun. Antti Suvanto tutkii nimittäin ammatillista kasvua Gestalt-psykologian valossa ja esittää sen antoisammaksi näkökulmaksi työssä oppimiseen ja organisaation kehittämiseen kuin behavioristiset ja psykoanalyyttiset lähestymistavat.

\section{Kirjan ensimmäisen} jakson päättää Pekka Ruohotien ja Petri Nokelaisen artikkeli, jossa kuvataan lineaarisen mallintamisen ja uuden, baynesiläisen mallintamisen eroja tutkimusaineiston luokittelutehtävissä. Tutkimusmetodisesti artikkeli on kiinnostava ja ajankohtainen, mutta jotenkin tuntui, että julkaisufoorumi ei ole aivan oikea. Tällaisen artikkelin olisi odottanut näkevänsä pikemminkin jossain tutkimus- ja analyysimenetelmiä käsittelevässä julkaisussa.

\section{Kirjan toinen osa koostuu} neljästä artikkelista. Reijo Raivola tarkastelee insinöörikoulutusta, teknistä suunnitteluprosessia ja siihen liittyvää ongelmanratkaisua erityyppisissä tehtävissä toimivien insinöörien haastatteluaineistoon pohjautuen. Seppo Kolehmainen käsittelee innovaatioiden leviämistä ammattikorkeakoulureformin yhteydessä ja Seija Mahlamäki-Kultanen kuvaa pedagogista johtajuutta metaforien avulla. Teoksen päättää Rauno Jarnilan tutkimukseen perustuva artikkeli menestyksellisen ammatillisen oppilaitoksen tulevaisuusprofiileista asiantuntijoiden näkemyksiin pohjautuen.

\section{Kirja tarjoaa runsaasti} käsitteellisiä aineksia ja empiirisiä tutkimustuloksia koulutuksen ja työelämän yhteistyön tarkasteluun, mutta kirjan otsikon houkuttelema lukija jäi kaipaamaan eksplisiittistä analyysia siitä, miten artikkeleissa tarjottuja aineksia voidaan hyödyntää koulutuksen ja työelämän yhteistyön kehittämisessä ja sen tutkimuksessa. Lisäksi kirjan painopiste on työntekijöiden ammatillisessa kehittymisessä, kun taas opiskelijoiden työssä oppimisen kysymyksiä lähinnä vain sivuttiin. Kokonaisuutena kirjasta jäi varsin sekava mielikuva. Artikkelit ovat monentasoisia ja keskenään varsin erilaisia, eikä niiden välillä tuntunut olevan yhtenäistä juonta. Vähintään olisi toivonut, että kirjan toimittajat olisivat koonneet kirjan lopussa näkökulmia yhteen ja osoittaneet lukijalle teemoja yhdistäviä kehittämishaasteita kirjan otsikon mukaisesti.

\section{Yhdessä nämä kaksi}

kirjaa tarjoavat työssä oppimisesta sekä koulutuksen ja työelämän yhteistyön kehittämisestä kiinnostuneille ajankohtaista ja vahvasti tutkimukseen ja teoriaan pohjautuvaa tietoa. Kivisen, Silvennoisen ja Puustellin toimittama kirja on lähestymistavoiltaan, otteiltaan ja tyyliltään huomattavasti yhtenäisempi kokonaisuus kuin Ruohotien, Hongan ja Suvannon, mutta tämä taas tarjoaa enemmän käytäntöön sovellettavissa olevaa tietoa. Kirjojen kotimaista lukijakuntaa tulee kuitenkin varmasti rajoittamaan kieli; monille työelämän ja koulutuksen käytännön sektorilla toimivalle englannin kieli on kynnys, jota ei työkiireiden keskellä helposti lähdetä ylittämään. Kirjat onkin ilmeisesti suunnattu kansainväliselle lukijakunnalle, sillä niiden teemat ovat ajankohtaisia kaikkialla maailmassa.

Kaija Collin ja Päivi Tynjälä 